\title{
Health Education about Stunting Nutrition in Mothers to Weight Stunting Children Aged 2-5 Years
}

\section{Risa Nurhayati, Rahayu Budi Utami, Ana Amelia Irawan}

School of Health Sciences Satria Bhakti, Nganjuk

Email:

ners.risa@gmail.com

Received : October 10, 2020

Accepted : November 22, 2020

Published : November 30, 2020

\begin{abstract}
Stunting or short is a failed condition to grow in toddler children due to chronic malnutrition, especially in the first 1000 days of life so that the child is too short for his age. Stunting toddlers tend to have low weight for their age.

The purpose of this research is to know the influence of health education on stunting nutrition in mothers to the weight of stunting toddlers aged 2-5 years

The research design used correlation with cohort experiment approaches. The study was conducted on 10 May-10 June 2020 in Gampeng village Ngluyu Sub-district of Nganjuk. The population and samples of 22 respondents were taken in total sampling. Independent variables were health education on stunting and weight-dependent variables of stunting toddlers. Data is collected using weight scales. Data analysis using Wilcoxon Sign Ranks with $\alpha=0.05$.

Weight of stunting toddlers before given health education half of which is 11 respondents (50\%) In the category of less weight, after health education was mostly 13 respondents $(59.1 \%)$ In the normal weight category. There was a health education influence on the stunting nutrients to the weight of stunting toddlers obtained the value of $\rho$-value $0.000 \leq \alpha$, so Ha accepted.

Health education is proven to be effective enough to improve the knowledge of mothers so that it can help to change the foster care of the mother in providing nutrition that has a good impact on weight gain in stunting toddlers.
\end{abstract}

Keywords: Health Education, Nutrition, Toddler, Stunting, Weight

Copyright (C) 2020 IIK STRADA Indonesia All right reserved.

This is an open-acces article distributed under the terms of the Creative Commons Attribution-ShareAlike 4.0 International License.

\section{BACKGROUND}

Stunting or short is a condition of failing to grow in infants (0-11 months) and toddlers (12-59 months) as a result of chronic malnutrition especially in the first 1000 days of life so that the child is too short for his age. Toddlers who experience stunting tend to be lower in weight than children their age (Sjarif, Lestari, Mexitalia, \& Nasar, 2011). Lack of nutritional intake for a long period of time from conception until the child is 2 years old. Children are often sick especially diarrhea, measles, tuberculosis and other infectious diseases, limited clean water and sanitation, food availability at low household level (M. Par'i, Wiyono, \& Harjatmo, 2017). The nutritional adequacy of toddlers is determined by practical knowledge of nutrition owned by mothers (Satriawan, 2018). One of the role 
of mother is as a careaer of the needs of the child. In this case it includes physical (feeding), psychic, social, and spiritual needs. Mothers with good parenting patterns will tend to have children with good nutritional status as well, as well as mothers with nutritional parenting patterns who are less likely to have children with less nutritional status (Ni'mah \& Muniroh, 2015).

Based on preliminary studies in the form of interviews with mothers who have stunting toddlers there are 11 mothers who say know about the causes of stunting and provide food according to the taste of the toddler such as rice with crackers. Five out of 16 mothers said they did not know the cause of stunting and feeding when the child asked without noticing a diet three times a day. Based on the data on the prevalence of toddler stunting collected WHO Indonesia belongs to the third country with the highest prevalence of stunting in Regional Southeast Asia / SEAR. The average prevalence of toddler stunting in Indonesia in 2005-2017 was 36.4\%. Meanwhile, based on data from Riskesdas in 2018 the prevalence of stunting in Indonesia reached 30.8\% (WHO, 2013). July 20, 2019 the prevalence of toddler stunting in East Java amounted to 36.81\%. In Nganjuk region the prevalence of stunting in 2018 was $16.1 \%$ and was the 9th in East Java and decreased to $11.87 \%$ in 2019. Ngluyu sub-district ranks first in Nganjuk Regency with a stunting prevalence of 21.3\% (122 toddlers). The number of stunting toddlers in Gampeng Village of Ngluyu District of Nganjuk Regency is as many as 30 toddlers (Dinkes Nganjuk, 2019).

(WHO, 2013) divides the causes of stunting into 4 major categories namely family and household factors, additional and complementary foods that are not strong, breastfeeding, and infection. Stunting is also caused by poor nutritional parenting practices before and during pregnancy and after motherhood (PERSAGI, 2013). The lack of maternal knowledge about health and nutrition so that the mother can not take a stance in providing proper nutritional intake. Inappropriate nutrient intake causes the child to experience malnutrition which eventually increases the incidence of morbidity and mortality ( Sari \& Kumorojati, 2019).

Various efforts were made by the Ministry of Health of the Republic of Indonesia in order to make the community aware of the nutritional problems that occurred. These efforts include specific nutritional interventions and sensitive nutritional interventions (Kemenkes RI, 2014). In Nganjuk Regency it self has made various efforts to deal with stunting problems namely stimulation-parenting and sustainable education. One of the government's efforts in tackling the problem of stunting is sensitive nutritional interventions that provide public nutrition education. Community nutrition education is provided through health eduation. Health education is able to improve maternal knowledge and behavior even though the child's growth does not increase directly (Ulfani, Martianto, \& Baliwati, 2011). Health education is necessary to form positive behaviors in terms of meeting nutritional needs as one of the important elements that support a person's health status especially in toddlers. In addition, health education is expected to change the maternal parenting pattern towards toddlers so that it has a good impact on weight gain (Supariasa, 2012).

\section{METHODS}

The research design uses correlation with the cohort experiment approach. The study was conducted from May 10 to June 10, 2020. The population of 22 respondents and a sample of 22 respondents were taken in total sampling. Independent variables are health education about nutritional stunting and dependent variables are toddler weight stunting. Data is collected using weight scales. Analyze data using Wilcoxon Sign Ranks with $\alpha=0.05$. The research design uses correlation with the cohort experiment approach. The study was conducted from May 10 to June 10, 2020. The population of 22 respondents and a sample of 22 respondents were taken in total sampling. Independent variables are health education about nutritional stunting and dependent variables are toddler weight stunting. Data is collected using weight scales. Analyze data using Wilcoxon Sign Ranks with $\alpha=0.05$.

\section{RESULTS}

\section{Weight loss toddler stunting before given health education about nutrition stunting}

Table 1. Distribution of the weight frequency of stunting toddlers before being given health education about nutrition stunting in Gampeng Village Ngluyu District Nganjuk Regency on May 10-June 10, 2020. 


\begin{tabular}{llll}
\hline No. & $\begin{array}{l}\text { Weight Loss Category } \\
(\mathbf{B B} / \mathbf{U})\end{array}$ & $\begin{array}{l}\text { Number } \\
(\text { Respondent) }\end{array}$ & $\begin{array}{l}\text { Percentage } \\
(\boldsymbol{\%})\end{array}$ \\
\hline 1. & Very under-weight & 1 & 4,5 \\
\hline 2. & Under-weight & 11 & 50,0 \\
\hline 3. & Normal weight & 10 & 45,5 \\
\hline 4. & More weight risk & 0 & 0 \\
\hline Total & & 22 & 100 \\
\hline
\end{tabular}

Based on table 1 it is known that out of 22 respondents half were as many as 11 respondents $(50 \%)$ have less weight before being given health education about nutritional stunting.

2. Weight loss of toddler stunting after being given health education about nutrition stunting

Table 2. Distribution of weight frequency of stunting toddlers after being given health education about nutrition stunting in Gampeng Village Ngluyu District Nganjuk Regency on May 10-June 10, 2020.

\begin{tabular}{llll}
\hline No. & $\begin{array}{l}\text { Weight Loss Category } \\
(\mathbf{B B} / \mathbf{U})\end{array}$ & $\begin{array}{l}\text { Number } \\
(\text { Respondent })\end{array}$ & $\begin{array}{l}\text { Percentage } \\
(\mathbf{\%})\end{array}$ \\
\hline 1. & Very under-weight & 0 & 0 \\
\hline 2. & Under-weight & 9 & 40,9 \\
\hline 3. & Normal weight & 13 & 59,1 \\
\hline 4. & More weight risk & 0 & 0 \\
\hline Total & 22 & 100 \\
\hline
\end{tabular}

Based on table 2 it is known that out of 22 respondents most of the 13 respondents (59.1\%) have a normal weight after being given health education about nutrition stunting.

3. The effect of health education on nutrition stunting on the weight of stunting toddlers aged 2-5 years in Gampeng Village Ngluyu District Nganjuk Regency

Table 3. Toddlers' weight stunting before and after given health education about nutrition stunting in Gampeng Village Ngluyu District Nganjuk Regency on May 10-June 10, 2020.

\begin{tabular}{|c|c|c|c|c|c|}
\hline \multirow[t]{2}{*}{ No } & \multirow{2}{*}{$\begin{array}{l}\text { Weight Loss } \\
\text { Category } \\
(\mathrm{BB} / \mathrm{U})\end{array}$} & Before & \multicolumn{3}{|c|}{ After } \\
\hline & & $\begin{array}{l}\text { Number } \\
\text { (Respondent) }\end{array}$ & $\begin{array}{l}\text { Percentage } \\
(\%)\end{array}$ & $\begin{array}{l}\text { Number } \\
\text { (Respondent) }\end{array}$ & $\begin{array}{l}\text { Percentage } \\
(\%)\end{array}$ \\
\hline 1. & $\begin{array}{ll}\text { Very under- } \\
\text { weight }\end{array}$ & 1 & 4,5 & 0 & 0 \\
\hline 2. & Under-weight & 11 & 50,0 & 9 & 40,9 \\
\hline 3. & Normal weight & 10 & 45,5 & 13 & 59,1 \\
\hline 4. & $\begin{array}{l}\text { More weight } \\
\text { risk }\end{array}$ & 0 & 0 & 0 & 0 \\
\hline Total & & 22 & 100 & 22 & 100 \\
\hline
\end{tabular}

Based on table 3 it is known that before being given health education half of the 11 respondents $(50 \%)$ have toddlers with less weight category. After being given health education most of the 13 respondents $(59.1 \%)$ have a toddler with a normal weight category. Wilcoxon Sign Ranks Test Results get $\rho$ value $=0.000 ; \alpha=0,05 ; \rho$ value $\leq \alpha$ so that Ha is accepted means there is a health education influence on nutrition stunting on mothers on the weight of stunting toddlers aged 2-5 years in Gampeng Village Ngluyu District Nganjuk Regency.

\section{DISCUSSION}

1. Weight loss toddler stunting before given health education about nutrition stunting

The results showed that half were 11 toddlers (50\%) Stunting aged 2-5 years in Gampeng Village Ngluyu sub-district had less weight before being given health education about stunting nutrition. 
Of the 11 toddlers who weighed less, most were 7 mothers (63.6\%) educated at junior high school level. Statistical results of contingency coefficients were obtained $\rho$ maternal education value $=$ $0.009 \leq(0.05)$. According to (Atmarita \& S. Fallah, 2014), education affects a person's level of knowledge. Because it is related to the attitude and mindset of the mother in paying attention to the toddler's eating intake ranging from seeking, obtaining and receiving various information about the toddler's eating intake. The higher the level of maternal education, the higher the mother's knowledge of food intake for her toddler and the easier it is for the mother to process information regarding her toddler's nutrition. The results of this study are also in line with (Fikawati \& Syafiq, 2005) stated that one's education is one of the important elements that can affect the state of nutrition in toddlers because with a higher level of education it is expected that knowledge or information about nutrition that parents have is better. Nutritional problems arise due to ignorance or lack of information about adequate nutrition.

Based on the results of the above research and theories shows that toddler weight stunting in the less category mostly occurs in toddlers with maternal education at the junior high school level. A person's level of education is closely related to insight into the source of nutrition and the type of food that is good for the family to consume. Educated mothers will tend to choose better food in quality and quantity, compared to mothers with lower education, but mothers who have a higher level of education sometimes less apply their knowledge with regard to the nutritional intake of toddlers whereas mothers who have a lower education they tend to seek information about food intake that is good for the toddler because knowledge is not only in formal school but can be obtained from various sources such as social media, nurses, midwives, nutrition officers puskesmas so as to add knowledge about the nutrition of toddlers.

\section{Weight loss of toddler stunting after being given health education about nutrition stunting}

The results showed that the majority were 13 toddlers (59.1\%) stunting aged 2-5 years in Gampeng Village Ngluyu sub-district has normal weight after being given health education tesntang nutrition stunting. Of the 13 toddlers who were of normal weight, most were 7 mothers (53.8\%) educated at the high school level. Statistical results of contingency coefficients were obtained $\rho$ maternal education value $=0.047 \leq(0.05)$.

The higher a person's education, the easier it is for the person to receive information. With higher education, then one tends to be easy to get information, both from others and from the mass media (Budiman \& Riyanto, 2013). According to (Soetjiningsih \& IGN Gde Ranuh, 2013) in the study (Nurmaliza \& Herlina, 2018) said that parental education is one of the important factors in nutritional status. Because with a good education, parents can receive all outside information about how good childcare is, especially how the mother gives food to the child, how to take care of the child's health, her education and so on. So the more knowledge and behavior that is expected will appear a good pattern of foster care.

From the results of the above research and theories can be concluded that the level of maternal education affects the mother's knowledge in feeding or nutrition in her toddler. High school education belongs to the category of secondary education so it is easier in receiving information about nutrition in stunting toddlers. The level of education can affect a person's learning process, the higher a person's education will be easy in receiving existing information. The more information that comes in, the higher the mother's knowledge of nutrition. So that the impact on feeding on stunting toddlers and the needs of toddlers can be sufficient

3. The effect of health education on nutrition stunting on the weight of stunting toddlers aged 25 years in Gampeng Village Ngluyu District Nganjuk Regency

The results of this study are known that toddler weight stunting before given health education about nutrition stunting is in the category of under-weight, while toddler weight stunting after being given health education about nutrition stunting is in the normal weight category. So after being given health education about nutrition stunting there was an increase in weight and evidenced from the results of the Wilcoxon Sign Ranks test with $\rho$ value $=0.000$, then $\mathrm{Ha}$ accepted, so there is a health education influence on nutrition stunting on mothers on toddler weight stunting. 
This research is supported by previous research conducted by (Saidah, 2010) namely nutrition education affecting the weight gain of toddlers. The education given to the mother of toddlers is in the form of knowledge about a healthy diet and examples of interesting foods. So it will have an impact on changes in the behavior of the toddler's mother in the toddler's parenting pattern and how to process interesting foods so that the toddler is excited when told to eat. In the study (Azria \& Huznah, 2016) showed that nutrition education can change the knowledge, skills, and attitude of the toddler's mother in fulfillment of food needs that affect the weight gain of toddlers. Nutrition education is quite effective and beneficial in terms of weight gain and nutritional status, decreased infectious diseases, and increased appetite of toddlers. This means that nutrition education can provide a new picture for toddler mothers in processing food variations so as to have an impact on the increase in toddler's appetite. Because in toddlers whose appetite is good will make nutritional status good so that the process of growing toddlers is not inhibited. In the study, it is explained that there is a influence of balanced nutrition counseling on the mother of toddlers on nutritional knowledge, where nutritional education is very effective given to change the attitude of the toddler's mother in providing nutritious food to toddlers. With good nutritional knowledge, the better the ability of the toddler's mother in determining, choosing, processing until presenting the daily nutrition menu.

Based on the results of this study, researchers argue that health education has been shown to increase the weight of stunting toddlers. This is because in health education there is a learning process. The learning process will improve one's knowledge. Knowledge will form an attitude, if one's knowledge is good then they will be positive so that ultimately forms a positive action anyway. Health education about nutrition stunting provided through video will facilitate the learning process, and can be played over and over again. The repeated learning process will make a person have sufficient behavior to perform the correct actions. What nurses, especially community nurses, can do to improve public health behavior, which is to routinely provide education about health to the community.

\section{CONCLUSION}

Based on the results of research and discussion, it can be drawn the conclusion of the study that there is a health education influence on nutrition stunting in the mother on the weight of stunting toddlers monitored for 1 month in Gampeng Village Ngluyu District Nganjuk Regency, where $\rho$ value $=0.000$ $\leq \alpha 0.05$, so ha is accepted. So it is recommended for mothers to implement proper nutrition in toddlers so that nutritional needs are met in a strong way so that stunting can be prevented and the process of growing toddlers is not inhibited, as well as for the next researchers to be able to develop methods of providing education about nutrition in stunting toddlers so that the goal of being able to lower stunting rates is achieved.

\section{ACKNOWLEDGMENTS}

I say thank you to respondents who are willing to be respondents in this study.

\section{CONFLICTS OF INTEREST}

No conflict of interest in this study.

\section{CITATION}

Atmarita, \& S. Fallah, T. (2014). Analisis Situasi Gizi dan Kesehatan Masyarakat. Direktorat Gizi Masyarakat . Jakarta: Widyakarya Nasional Pangan dan Gizi VIII.

Azria, C., \& Huznah. (2016). Pengaruh Penyuluhan Gizi Terhadap Pengetahuan Dan Perilaku Ibu Tentang Gizi Seimbang Balita Kota Banda Aceh. Jurnal Kedokteran Syiah Kuala.

Budiman, \& Riyanto, A. (2013). Kapita Selekta Kuesioner Pengetahuan dan Sikap dalam Penelitian Kesehatan . Jakarta: Salemba Medika.

Dinkes Nganjuk. (2019). Angka Prevalensi Stunting Tertinggi di Kabupaten Nganjuk Tahun 2019 (Januari s/d Februari). Nganjuk: Dinas Kesehatan Kabupaten Nganjuk. 
Fikawati, S., \& Syafiq, A. (2005). Konsumsi Kalsium pada Remaja, Gizi dan Kesehatan Masyarakat. Universitas Indonesia, Depertemen Gizi dan Kesehatan Masyarakat Universitas Indonesia. Jakarta: Raja Grafindo Persada.

Kemenkes RI. (2014). Kondisi Pencapaian Program Kesehatan Anak Indonesia. Jakarta: Indoftin.

M. Par'i, H., Wiyono, S., \& Harjatmo, T. P. (2017). Penilaian Status Gizi. Jakarta: Kementerian Kesehatan Republik Indonesia.

Ni'mah, C., \& Muniroh, L. (2015, Januari-Juni). Hubungan Tingkat Pendidikan, Tingkat Pengetahuan Dan Pola Asuh Ibu Dengan Wasting Dan Stunting Pada Balita Keluarga Miskin. Media Gizi Indonesia, 10, 84-90.

Nurmaliza, \& Herlina, S. (2018). Hubungan Pengetahuan Dan Pendidikan Ibu Terhadap Status Gizi Balita. Jurnal KesMARS, 44-48.

PERSAGI. (2013). Stop Stunting Dengan Konseling Gizi. Jakarta: Penebar Plus (Penebar Swadaya Grup).

Sari, A. A., \& Kumorojati, R. (2019). Hubungan Pemberian Asupan Makanan Pendamping Asi (Mpasi) Dengan Pertumbuhan Bayi/Anak Usia 6-24 Bulan. Jurnal Kebidanan dan Kesehatan Tradisional, 57-119.

Saidah, N. (2010). Pengaruh Penyuluhan Gizi Terhadap Status Gizi, Perkembangan Fisik Dan Psikososial Balita (Usia 2 - 5 Tahun) (Di Desa Penatarsewu Tanggulangin Sidoarjo Jawatimur). Jurnal Gizi Indonesia.

Satriawan, E. (2018). Strategi Nasional Percepatan Pencegahan Stunting 2018-2024. Jakarta: Tim Nasional Percepatan Penanggulangan Kemiskinan(TNP2K) Sekretariat Wakil Presiden Republik Indonesia.

Sjarif, D. R., Lestari, E. D., Mexitalia, M., \& Nasar, S. S. (2011). Buku Ajar Nutrisi Pediatrik dan Penyakit Metabolik. Jakarta: Badan Penerbit Ikatan Dokter Anak Indonesia.

Soetjiningsih, \& IGN Gde Ranuh. (2013). Tumbuh Kembang Anak. Jakarta: EGC.

Supariasa, I. N. (2012). Pendidikan dan Konsultasi Gizi. Jakarta: EGC.

Ulfani, D. H., Martianto, D., \& Baliwati, Y. F. (2011). Faktor-Faktor Sosial Ekonomi Dan Kesehatan Masyarakat Kaitannya Dengan Masalah Gizi Underweight, Stunted, Dan Wasted Di Indonesia: Pendekatan Ekologi Gizi. Jurnal Gizi dan Pangan, 59-65. doi:https://doi.org/10.25182/jgp.2011.6.1.59-65

WHO. (2013). Chilhood Stunting: Context, Cause, and Consequences. Maternal and Child Nutrition. World Health Organization. 